\title{
Anti-Inflammatory Effects of Magnetically Targeted Mesenchymal Stem Cells on Laser-Induced Skin Injuries in Rats [Corrigendum]
}

Li X, Wei Z, Zhang W, et al. Int $J$ Nanomedicine. The correct Figure 5 is shown below.

2020;15:5645-5659.

The authors have advised due to an error that occurred at

The authors apologize for this error and advise it does not the time of figure assembly the incorrect image was affect the results and conclusions of the paper.

selected for the MSC group in Figure 5A on page 5654

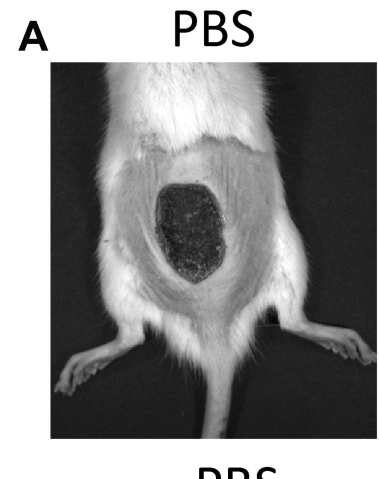

B
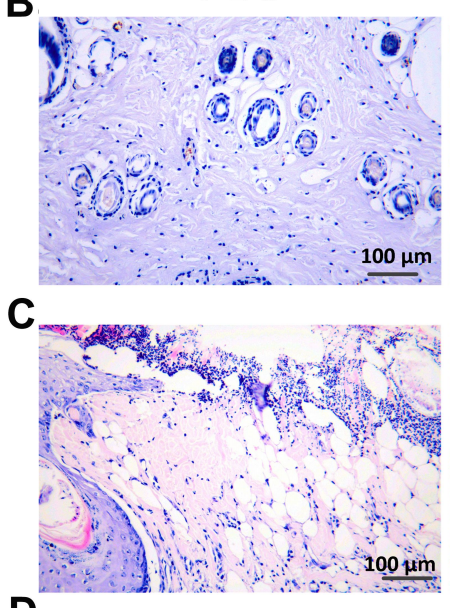

D
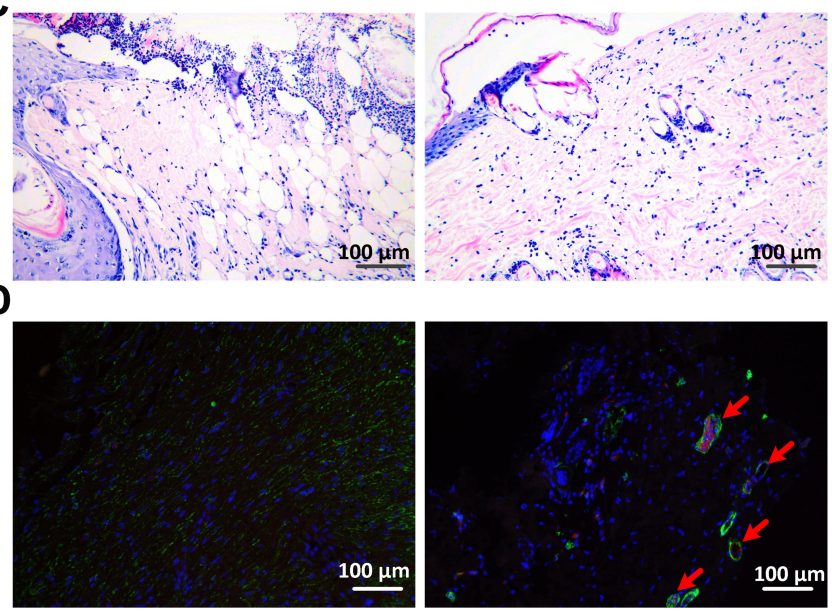

MSC
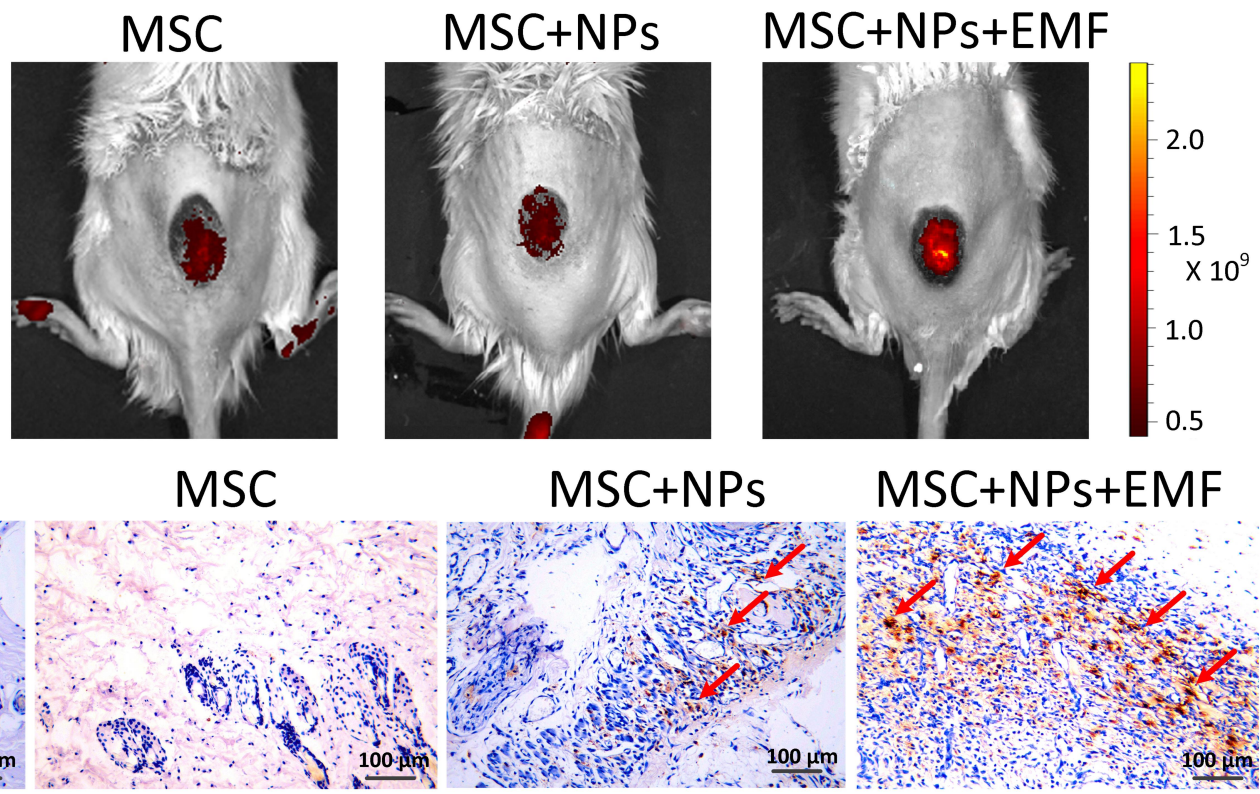

MSC+NPs
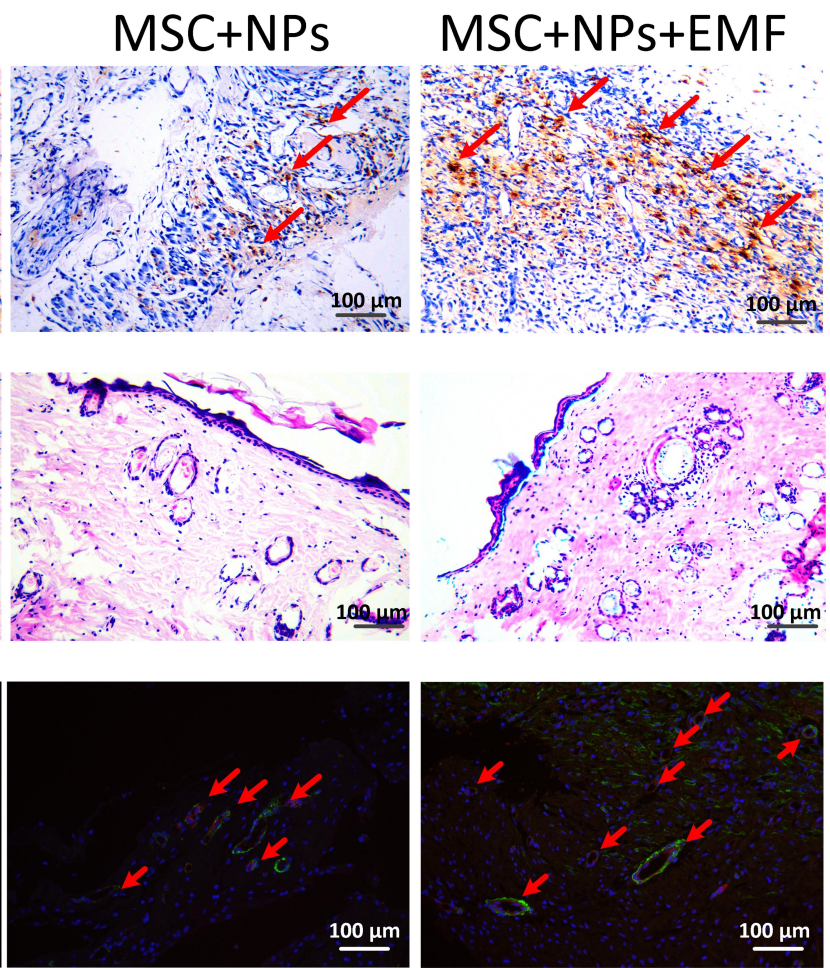

Figure 5 MSC migration to the burn injury lesions and their therapeutic effects in the rat model. (A) The live imaging of MSCs, labeled MSCs, and magnetically targeted MSCs in rats with burn injuries. (B) DAB-enhanced Prussian blue staining of skin sections at 7 days revealed that $\mathrm{Fe}_{3} \mathrm{O}_{4} \mathrm{NPs}$ remained in the skin tissues. The red arrow indicates yellowish brown iron deposits. Scale bar $=100 \mu \mathrm{m}$. (C) Histological features of skin sections from the burned area stained with $\mathrm{H} \& \mathrm{E}$ at 7 days after burn induction. Scale bar $=100 \mu \mathrm{m}$. (D) Immunofluorescence staining for CD3I and $\alpha$-SMA in wounds after treatment with PBS, MSCs, MSCs labeled Fe $\mathrm{O}_{4} \mathrm{NPs}_{\mathrm{S}}$ or magnetically targeted MSCs 7 days post-wounding. The red arrow indicates vessels. Scale bar $=100 \mu \mathrm{m}$.

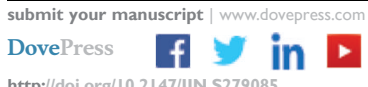




\section{Publish your work in this journal}

The International Journal of Nanomedicine is an international, peerreviewed journal focusing on the application of nanotechnology in diagnostics, therapeutics, and drug delivery systems throughout the biomedical field. This journal is indexed on PubMed Central, MedLine, CAS, SciSearch ${ }^{\circledR}$, Current Contents ${ }^{\circledR} /$ Clinical Medicine, $^{2}$
Journal Citation Reports/Science Edition, EMBase, Scopus and the Elsevier Bibliographic databases. The manuscript management system is completely online and includes a very quick and fair peer-review system, which is all easy to use. Visit http://www.dovepress.com/ testimonials.php to read real quotes from published authors. 